\title{
Estimation of ecological exergy using weighing parameters determined from DNA contents of organisms - a case study
}

\author{
Júlio C. Fonseca ${ }^{1}$, Miguel A. Pardal ${ }^{1}$, Ulisses M. Azeiteiro ${ }^{1,2}$ \& João C. Marques ${ }^{1}$ \\ ${ }^{1}$ IMAR - Institute of Marine Research, Department of Zoology, University of Coimbra, Portugal \\ Tel: +351-239-836386.Fax: +351-239-823603.E-mail: jfonseca@ci.uc.pt \\ ${ }^{2}$ Department of Science and Technology, Portuguese Open-University, Portugal
}

Key words: ecosystem, eutrophication, exergy, management, ecological orientor

\begin{abstract}
We studied the changes of exergy and specific exergy with data of benthic macrofauna communities, periodically sampled along an estuarine gradient of eutrophication in the Mondego estuary (Western Portugal). Exergy estimates were calculated from organism biomass, based on weighing factors for the relative content of exergy per unit of biomass determined from DNA contents of organisms. Results were discussed in terms of both the macrofauna biomass production and the structural organisation of the system. Estimates for the exergy indices provided useful indications for the evaluation of environmental impact due to the eutrophication process. Different average values for the indices of exergy and specific exergy were estimated relatively to areas with different levels of eutrophication, in the 'spatial' gradient of eutrophication. Higher exergy levels and lower exergy content per unit of biomass (specific exergy) were associated to populations more stabilized or areas less perturbed. Additionally, the index of specific exergy seemed capable of providing indications for the qualitative alterations in the communities (in temporal and spatial terms) that go in the direction of the observations made in this ecosystem.
\end{abstract}

\section{Introduction}

With regard to environmental management, efforts have been directed to the identification and description of certain ecosystem features, which are regularly changed by self-organising ecological development (Odum, 1969; May, 1974; Wilson, 1975; Odum, 1983; Okubo, 1986; Weber et al., 1989; Costanza et al., 1992; Jørgensen, 1992; Jørgensen et al., 1992; Woodley et al., 1993; Schneider \& Kay, 1994a; Müller, 1997; Baird, 1998). These systems attributes can be described as emergent or collective properties which are expected to be regularly optimised during ecosystems development (Müller 1996; Wiegleb \& Bröring, 1996; Bröring \& Wiegleb, 1998; Bossel, 1998; Müller $\&$ Fath, 1998). This means that certain states of such attributes can be taken as ecological orientors (Bossel, 1992) or attractors, that is, stages that an ecological system usually develops towards (Bossel, 1992, 1998; Patten, 1997; Müller \& Fath, 1998). Such orientors, described as aspects, notions, properties, or dimen- sions of systems, are useful criteria to describe and evaluate the system's developmental stage as ecological indicators with a more broad perspective (Bossel, 1992, 1998; Schneider \& Kay 1994a, b; Müller et al., 1998; Müller \& Fath, 1998; Jørgensen \& Nielsen, 1998; Marques \& Nielsen, 1998; Marques et al., 1998a, b; Kutsch et al., 1998). In a modelling context, the general properties indicated by the orientors are technically translated in terms of mathematical algorithms designated as goal functions (Müller \& Fath, 1998; Bossel, 1998; Jørgensen \& Nielsen, 1998b; Nielsen et al., 1998). This permits the development of models with a more dynamic structure, which means models with parameters (properties) that can change according to certain goal functions (Nielsen, 1990, 1992, 1995; Jørgensen, 1992c; Jørgensen \& Nielsen, 1998a, b; Nielsen et al., 1998). This way, these structural dynamic models include and describe changes in species composition and trophic structure of ecosystems (Nielsen, 1994, 1995; Bastianoni \& Marchenttini, 1997; Jørgensen \& Bernardi, 1997; 
Jørgensen \& Nielsen, 1998b; Nielsen et al., 1998), resulting in an improved predictive capability and better environmental management (Jørgensen \& Nielsen, 1998b; Marques et al., 1998a, b; Marques \& Nielsen, 1998; Nielsen et al., 1998; Zölitz-Möller \& Herrmann, 1998).

Some orientors have 'emerged' from interdisciplinary discussions embracing the fields of Thermodynamics, Succession Theory, and Network Theory (Bass, 1998; Bröring \& Wiegleb, 1998; Jørgensen \& Nielsen, 1998a, b; Marques et al., 1998a, b; Patten, 1998; Svirezhev, 1998; Ulanowicz, 1998). The exergy is a concept derived from Thermodynamics, interpreted as a function expressing energy with a built-in attribute of quality (in terms of energy potential to perform work) (Jørgensen \& Mejer, 1977, 1979, 1981; Jørgensen, 1992a), a measure of the contrast between a system and its surrounding environment (Wall, 1986; Schneider \& Kay, 1994b; Jørgensen \& Nielsen, 1998a), or an estimate for the maximum capacity of energy to perform useful work as the system proceeds to equilibrium with its surroundings (Brzustowski \& Golem, 1978; Ahern, 1980. Quoted from: Schneider \& Kay, 1994a). It has been suggested as a potential indicator of ecosystems state of development and health (Nielsen, 1990; Jørgensen et al., 1995; Fuliu, 1997; Marques et al., 1997, 1998b, b; Müller, 1997). The ecosystem's ability of self-organization permits it to deal with external changes/perturbations, and in response the system may reorganize its structure and functioning (e.g. matter gradients, trophic relations, flows of energy, etc.) (Søndergaard et al., 1990; Zhou et al., 1996; Jørgensen \& Padisak, 1996; Marques et al., 1998a; Jørgensen \& Nielsen, 1998b). In time, the systems evolve to different states of 'contrast' relative to their surroundings, and consequently their departure from thermodynamic equilibrium will be associated to their actual states of development (Jørgensen, 1992; Schneider \& Kay, 1994a, b). Therefore, it has been suggested that changes of exergy can be indicative of alterations in ecosystem structure or functioning, and be useful in methodologies for the environmental management from a enhanced point of view.

Due to the high complexity of ecosystems, direct measurements of exergy are not feasible as we cannot consider and make estimations of the properties for all the components of an ecosystem. Nevertheless, in the context of environmental management, it is acceptable to use models considering only the components of a system more relevant for solving a particular prob- lem. This way the indirect estimation of exergy is achievable regarding the system's (model) composition. This function is computed as a global summation for the components of a system (model), where each term of the global sum takes into account the relative concentration of the corresponding component and its relative departure from a thermodynamic reference state expressed in terms of its exergy content (Mejer \& Jørgensen, 1979; Jørgensen et al., 1995). Considering detritus (dead organic matter) as a common reference state, the departure from this reference state for each (living) component, is achieved by the combination of the probability of producing detritus and the probability associated with the component's genomic dimension in terms of its genome 'maximum coding capacity' (Jørgensen et al., 1995; Fonseca et al., 2000). Exergy may also be expressed by the ratio of exergy to the total biomass of the system, being referred to as the specific exergy of the system, thus expressing the exergy content per unit of biomass in the system, for a given moment.

In this study, we have obtained estimates of ecological exergy and specific exergy from biomass data of benthic macrofauna communities, periodically sampled along an estuarine gradient of eutrophication in the Mondego estuary (Western Portugal) (Marques et al., 1997; Pardal, 1998). We aimed to investigate to what extent the estimation of ecological 'exergistic' indicators can assist in the assessment of the structural organisation and functioning of the system.

\section{Description of sites studied}

The Mondego estuary consists of two arms surrounding a small island (the Murraceira island), joining at about $1 \mathrm{~km}$ from the sea (Fig. 1). The two arms differ in terms of hydrological, physical, chemical, and sediments characteristics: the northern arm is deeper (4-8 $\mathrm{m}$ during high tide, variable tide amplitude of 2-3 m) than the southern arm, which is almost completely silted up in the upstream areas (Duarte \& Reis, 1993; Marques et al., 1993, 1997; Pardal 1998). Consequently the freshwater discharges occur mainly through the northern arm, while water circulation in the southern arm is dependent on the tides and the discharges of freshwater from a tributary (the Pranto river) that is controlled by a sluice. The south arm can be considered almost as a coastal lagoon system in terms of hydrological properties (Marques, 1989; Marques et al., 1993, 1997; Pardal 1998; Lillebø et al., 


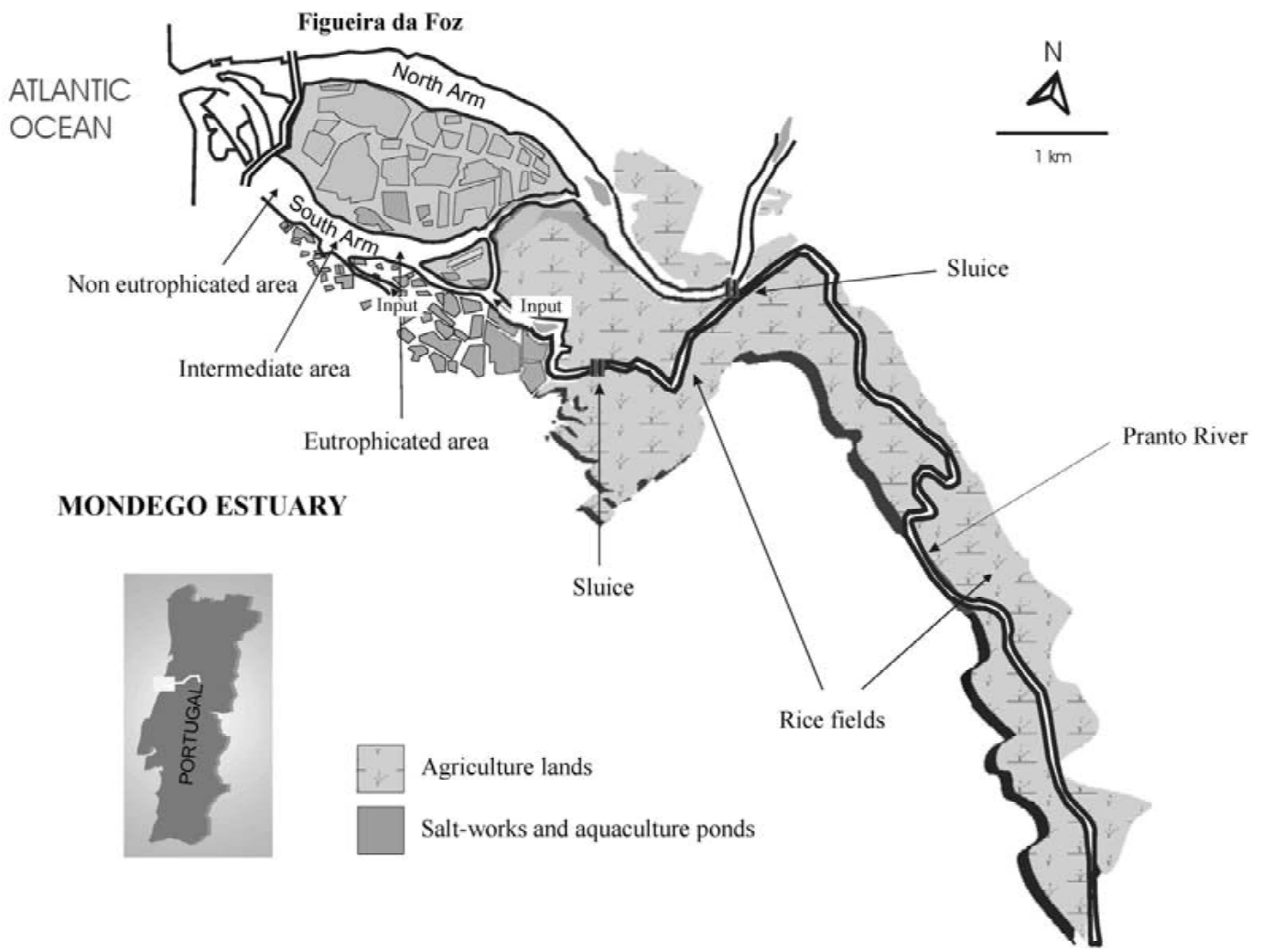

Figure 1. Representation of the Mondego estuary (Western Portugal) with the location of the sampling stations along the gradient of eutrophication.

1999; Martins et al., 2000), with a considerably higher residence period of water bodies in the inner areas of the south arm than in the north arm (Pardal, 1998).

This estuary is the localization of many harbor functions (both commercial and recreational purposes), salt-works, and 'fish-farms'. It is also the receiver of discharges of urban and industrial sewerage systems, and chemical compounds (e.g. fertilizers and pesticides) from farmlands (mostly rice-fields) located in upstream areas (Marques et al., 1993; Pardal, 1995; Flindt et al., 1997; Azeiteiro, 1999). The drainage from farmlands represents a significant discharge of nutrients (e.g. nitrogen and phosphorous) into the water column (134 tons/year of nitrogen) (Flindt et al., 1997; Pardal, 1998). This fact and the level of confinement of the southern arm of the estuary contribute to the eutrophication of the system along a spatial gradient. As a consequence of this eutrophication process, qualitative changes have been verified in this ecosystem, where a progressive replacement of a macrophyte community, consisting of slow growing species (Zostera), by free floating (or partially, float- ing), fast growing species (e.g. Enteromorpha spp.) is being observed. This shift in primary producers may have consequences on the structure of communities, reflected in its specific composition, with the dominance of $r$ strategists in more eutrophicated areas, and, in general, on the system's productivity, which may result in a new trophic structure (Marques et al., 1998a; Pardal, 1998; Lillebø et al., 1999; Lopes et al., 2000; Pardal et al., 2000).

In this study, we have considered three study areas along the gradient of eutrophication. The less affected area, considered as non-eutrophied, is by the mouth of the south arm of the estuary, where a macrophyte community (Zostera noltii) can be found. We designate this area as the Zoostera meadows. On the other hand, the most affected area (eutrophied) is localised at a more upstream area, where the macrophytes have disappeared in the course of the last decade. Here green-macroalgae blooms occur, essentially of Enteromorpha spp., depending upon the weather conditions verified each year (Pardal, 1998; Pardal et al., 2000; Martins et al., 2000). A third study area was localised 
between the other two areas and regarded as an area at a stage of intermediate eutrophication (Pardal, 1998; Lillebø et al., 1999; Pardal et al., 2000).

\section{Material and methods}

\section{Sampling and laboratory procedures}

This study corresponds to a period of 13 months, from February 1993 to March 1994. During this period of time, samples of macrophytes, macroalgae, and associated macrofauna were collected, during low water tide, every 2 weeks at the three study sites described above (A - Zoostera meadows; B - intermediate eutrophied; and C - highly eutrophied) (Fig. 1) (Pardal, 1998; Lillebø et al., 1999; Pardal et al., 2000). Cores (10 cores per site; $143 \mathrm{~cm}$ of section; $15 \mathrm{~cm}$ depth) were placed individually in plastic bags and sieved (500 $\mu \mathrm{m}$ mesh) using estuarine water within an hour of sampling. The retained materials (sediment, macrophytes or algae, and macrofauna) were transferred to plastic bottles and preserved with $4 \%$ formalin in estuarine water. Macroinvertebrates were gathered and identified almost always to the species level. Afterwards, the correspondence into trophic collections (herbivores, filter feeders, detritus feeders, carnivores, and omnivores) was established (Pardal, 1998). Materials were dried at $60^{\circ} \mathrm{C}$ for $72 \mathrm{~h}$ and weighed to the nearest $0.01 \mathrm{mg}$. Samples were subsequently combusted for $8 \mathrm{~h}$ at $450{ }^{\circ} \mathrm{C}$ and the correspondent biomass estimated and expressed as $\mathrm{g} \cdot \mathrm{m}^{-2}$ AFDW (Pardal, 1998).

\section{Exergy estimation}

Estimates of ecological exergy (Ex) and specific exergy ( $\mathrm{spEx}$ ) were calculated from the biomass of organisms $\left(\mathrm{g} \cdot \mathrm{m}^{-2}\right.$ AFDW) using weighing factors for the specific exergy content of biomass for each component of the system (model). Approximate estimates of ecological exergy (Ex) were given by Jørgensen et al. $(1995,2000)$ :

$$
\mathrm{Ex} \approx \sum_{i=1}^{N} \beta_{i} \cdot c_{i},
$$

where $c_{i}$ is the concentration of the component $i$ (e.g. biomass of a given taxonomic group or functional group) in the system with $N$ components, and $\beta_{i}$ is a 'weighing factor' expressing the specific exergy
Table 1. Weighing factors $(\beta)$ to estimate exergy for different groups of organisms. The concentration of each organism was multiplied by the respective weighing factor to estimate the exergy content of biomass as described in Jørgensen et al. (1995). Parameters provided in Fonseca et al. (2000) were determined using nuclear DNA contents of organisms

\begin{tabular}{lc}
\hline Organisms/system compartments & Weighing factor $\beta$ \\
\hline 'Detritus' & 1 \\
Annelids & 50 \\
Polychaets & \\
Arthropods & 70 \\
Insects & 230 \\
Crustaceans & \\
Molluscs & 450 \\
Gastropods & 760 \\
Bivalves & \\
Echinoderms & 360 \\
Asteroideans/Echinoideans & \\
Chordates & 800 \\
Fish & \\
\hline
\end{tabular}

content per unit of biomass for that component. We used weighing factors $(\beta)$ determined from organisms' DNA content (C-values) as described in Fonseca et al. (2000) (Table 1). In brief, the total 'genome' lengths of organisms are estimated from the DNA content in cells nuclei (their corresponding 'C-values'), and assumed as topmost limits for the 'overall coding capacity' of organisms' genomes. Then, these estimates can be 'converted' into probabilities associated to the genetic information content of organisms and used to calculate the parameters $(\beta)$ to weigh the exergy content per unit of biomass from organisms. Results were expressed as $\mathrm{g}$ detritus exergy equivalents $\cdot \mathrm{m}^{-2}$, since detritus $(i=1)$ was considered as a reference state for the computation of exergy estimates. Estimates of specific exergy (spEx) were given by the ratio of ecological exergy (Ex) to the total biomass of the system (Biom.Total) for each instant, according to (Jørgensen \& Nielsen, 1998b):

$$
\operatorname{spEx}=\mathrm{Ex} / \text { Biom. } . \text { Total. }
$$

Therefore, results were expressed as exergy·unit of biomass $^{-1}$.

\section{Results}

The values obtained for the annual biomass $\left(\mathrm{g} \cdot \mathrm{m}^{-2}\right.$ AFDW) of macrofauna found in each of the three stud- 

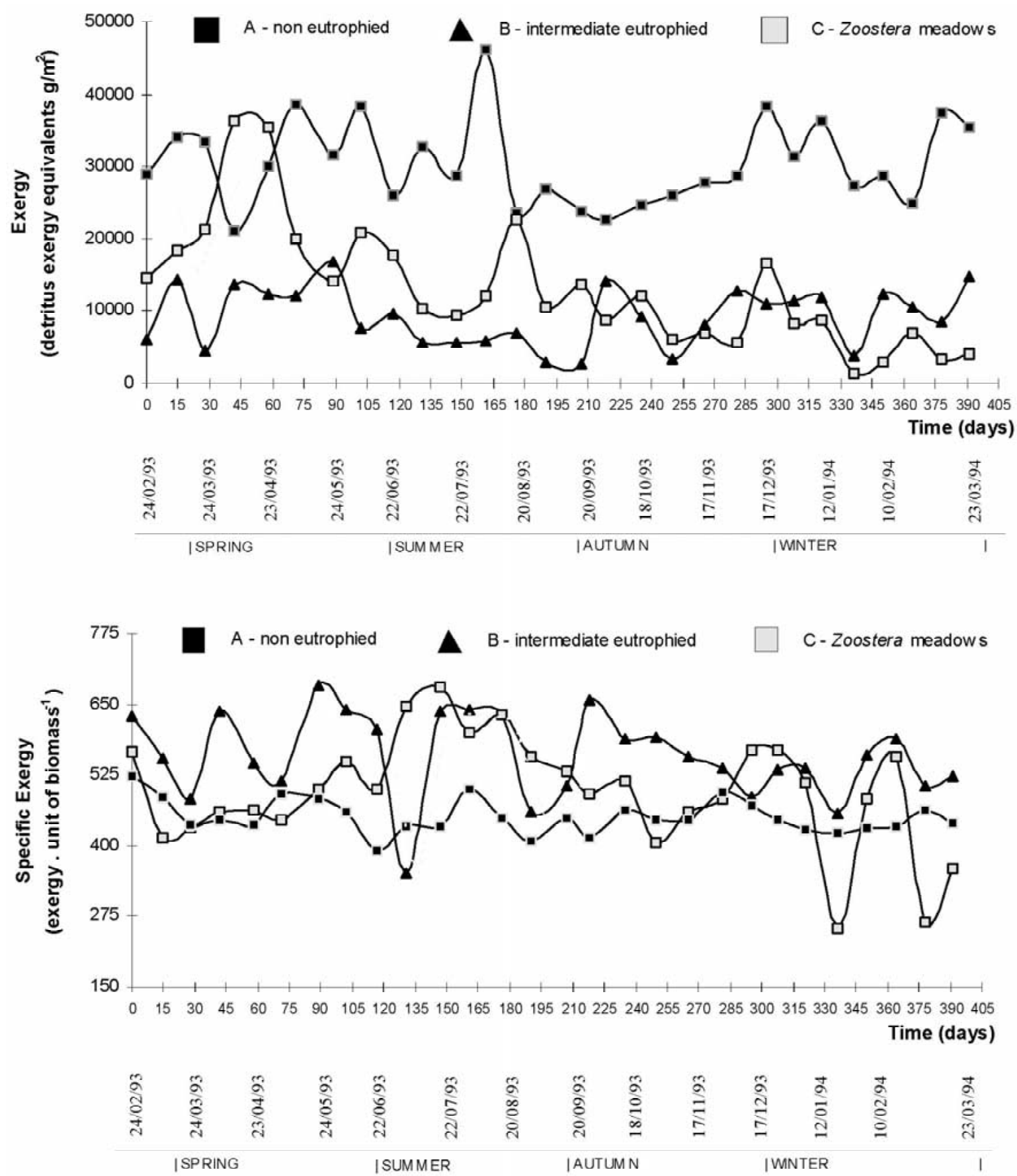

Figure 2. Variation of exergy (2.1) and specific exergy (2.2) in Zoostera meadows (A), intermediate eutrophied (B) and most eutrophied (C) areas in the Mondego estuary, for the period from to 24th of February 1993 to 23rd of March 1994. Exergy (2.1) was estimated from the macrofaunal biomass based on the use of weighing factors. The exergy content per unit of biomass was estimated from the total biomass for the period considered. 

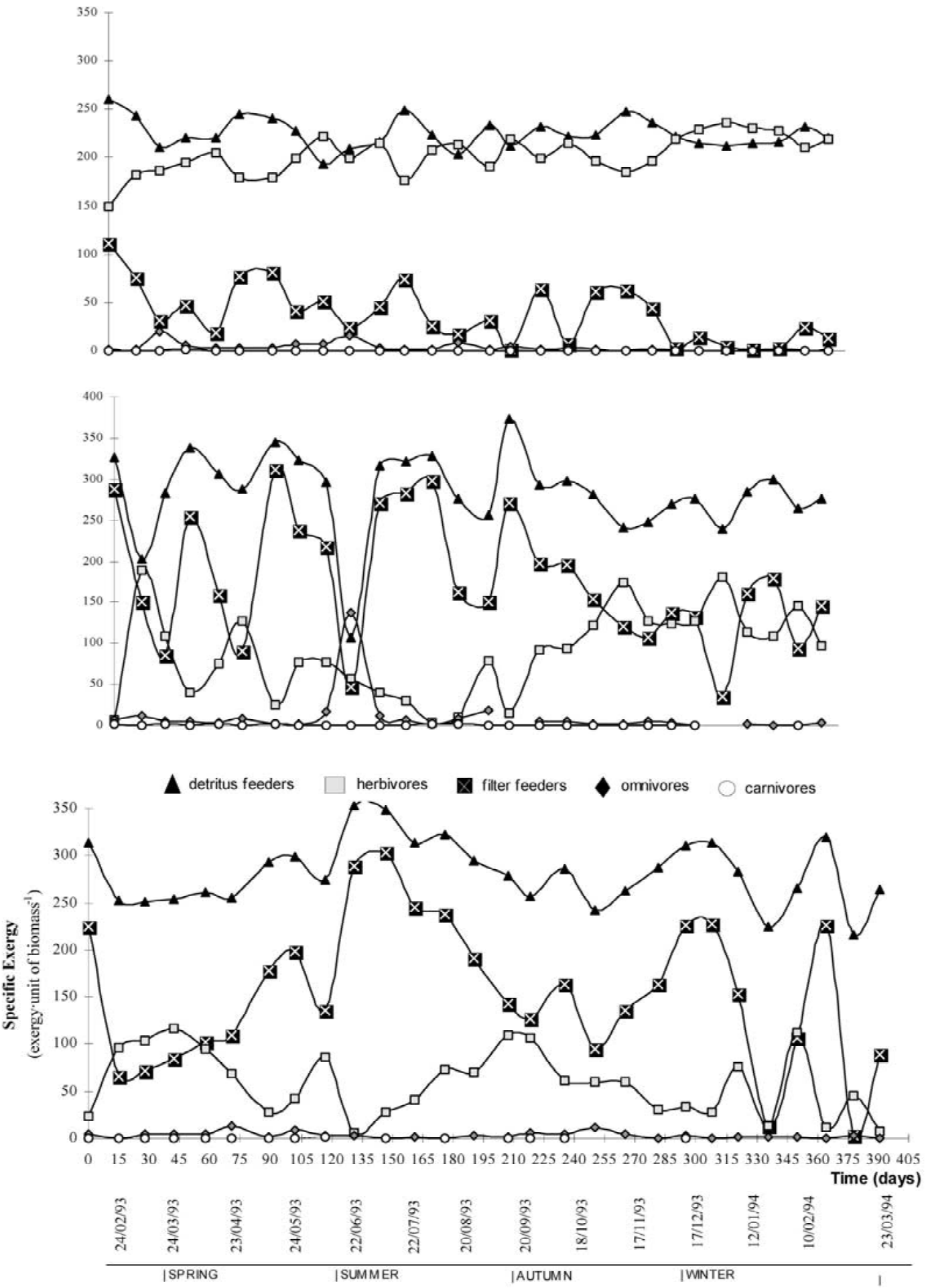

Figure 3. Variation of macrofaunal biomass in the Zoostera meadows (3.1), intermediate eutrophied (3.2) and most eutrophied (3.3) areas in the Mondego estuary, considering organisms assemblaged into trophic guilds (herbivores, filter feeders, detritus feeders, carnivores, and omnivores). 
Table 2. Annual and average annual values of biomass density, exergy and specific exergy associated to the macrofauna found along the gradient of eutrophication in the Mondego estuary, for the period from to 24th of February 1993 to 23rd of March 1994

\begin{tabular}{|c|c|c|c|c|}
\hline \multirow[t]{2}{*}{ System features: } & & \multicolumn{2}{|l|}{ Study sites } & \multirow[b]{2}{*}{$\begin{array}{l}\mathrm{C} \\
\text { highly } \\
\text { eutrophied }\end{array}$} \\
\hline & & $\begin{array}{l}\text { A } \\
\text { Zoostera } \\
\text { meadows }\end{array}$ & $\begin{array}{l}\text { B } \\
\text { eutrophied }\end{array}$ & \\
\hline $\begin{array}{l}\text { Biomass } \\
\left(\mathrm{g} \cdot \mathrm{m}^{-2}\right)\end{array}$ & $\begin{array}{l}\text { Annual } \\
\text { Average }^{a}\end{array}$ & $\begin{array}{l}1893 \\
68 \pm 12\end{array}$ & $\begin{array}{l}461 \\
16 \pm 7\end{array}$ & $\begin{array}{l}743 \\
27 \pm 19\end{array}$ \\
\hline $\begin{array}{l}\text { Exergy } \\
\left(\mathrm{g} \text { detritus exergy equivalent } \cdot \mathrm{m}^{-2} \text { ) }\right.\end{array}$ & $\begin{array}{l}\text { Annual } \\
\text { Average }^{a}\end{array}$ & $\begin{array}{l}853961 \\
30499 \pm 5964\end{array}$ & $\begin{array}{r}258250 \\
9223 \pm 4046\end{array}$ & $\begin{array}{rl}368 & 572 \\
13 & 163 \pm 8718\end{array}$ \\
\hline $\begin{array}{l}\text { Specific Exergy } \\
(\text { exergy·unit of biomass }\end{array}$ & $\begin{array}{l}\text { Annual } \\
\text { Average }^{a}\end{array}$ & $\begin{array}{l}12616 \\
\quad 451 \pm 29.8\end{array}$ & $\begin{array}{l}15645 \\
559 \pm 75.2\end{array}$ & $\begin{array}{rl}13 & 891 \\
& 496 \pm 100.3\end{array}$ \\
\hline
\end{tabular}

Average $^{a}=$ average annual value \pm standard deviation.

ied sites (A - Zoostera meadows; B - eutrophied; C - highly eutrophied) are given in Table 2 . The estimates of exergy (detritus exergy equivalent $\mathrm{g} \cdot \mathrm{m}^{-2}$ ) and specific exergy (exergy.unit of biomass ${ }^{-1}$ ) associated with the biomass, are found in this table, also. The annual variation of biomass and the corresponding contributions associated to each trophic guild are depicted in Figures 2 and 3, respectively. The exergy content per unit of biomass (specific exergy) is represented in Figure 4, with regard to the contributions from organisms' biomass in terms of trophic groups (detritus feeders, herbivores, filter feeders, carnivores and omnivores). In Figure 5, the biomass of primary producers from the studied areas is represented: macrophytes correspond to biomass of Zostera noltii and macroalgae to biomass of Ulva, Chaetomorpha, and Enteromorpha.

The highest annual standing stock of macrofauna biomass (Table 2) was verified in the less eutrophied area (study site A - Zoostera meadows), corresponding to the Zostera noltii community. The biomass values in the most eutrophied area (study site C - highly eutrophied; macroalgae community) were higher than in the less eutrophied area (study site B - eutrophied). The same pattern was found with regard to the estimates of exergy (Table 2). On the contrary, the annual average estimate of structural exergy for the study site B (559 \pm 75.2 ; units: exergy unit of biomass $\left.{ }^{-1}\right)$ was higher than the average estimates determined for the other two areas (A: $451 \pm 29.8$; C: $496 \pm 100.3$; units: exergypunit of biomass ${ }^{-1}$ ). With regard to the specific exergy landscapes as depicted in Figure 4, the specific exergy contributions of the several trophic guilds in the area B seem to oscillate between the levels found in the areas A and C. Moreover, the exergy content per unit of biomass of detritus feeder and filter feeder organisms are higher in the eutrophied areas, especially for the filter feeder organisms during late spring and early summer (Fig. 4).

As shown in Figure 5, during spring and early summer, the Enteromorpha bloom contributed to the high levels of macroalgae in the most eutrophied area (study site C), but was followed by the macroalgae crash, corresponding to a drastic reduction of the total biomass. In area $\mathrm{B}$ the densities of macroalgae were lower than in the most eutrophied area (site C), but its levels were maintained longer in time, until early autumn.

\section{Discussion and final remarks}

Ecosystems may be considered as complex systems resulting from "biotic, physical, and chemical components of nature acting together as a non-equilibrium dissipative process" (Schneider \& Kay, 1994a). Like the living organisms, ecosystems use high quality energy as 'fuel' in metabolic processes of matter and energy conversion, enabling them to maintain their structure or increase its internal order (Schrödinger, 1944; Jørgensen et al., 1999). The energy quality can be understood in terms of work potential of the system relatively to a state of equilibrium (Wark, 1995), its exergy content. High quality energy means a higher exergy content and, on the other hand, low quality energy implies an energy of lower potential to perform 

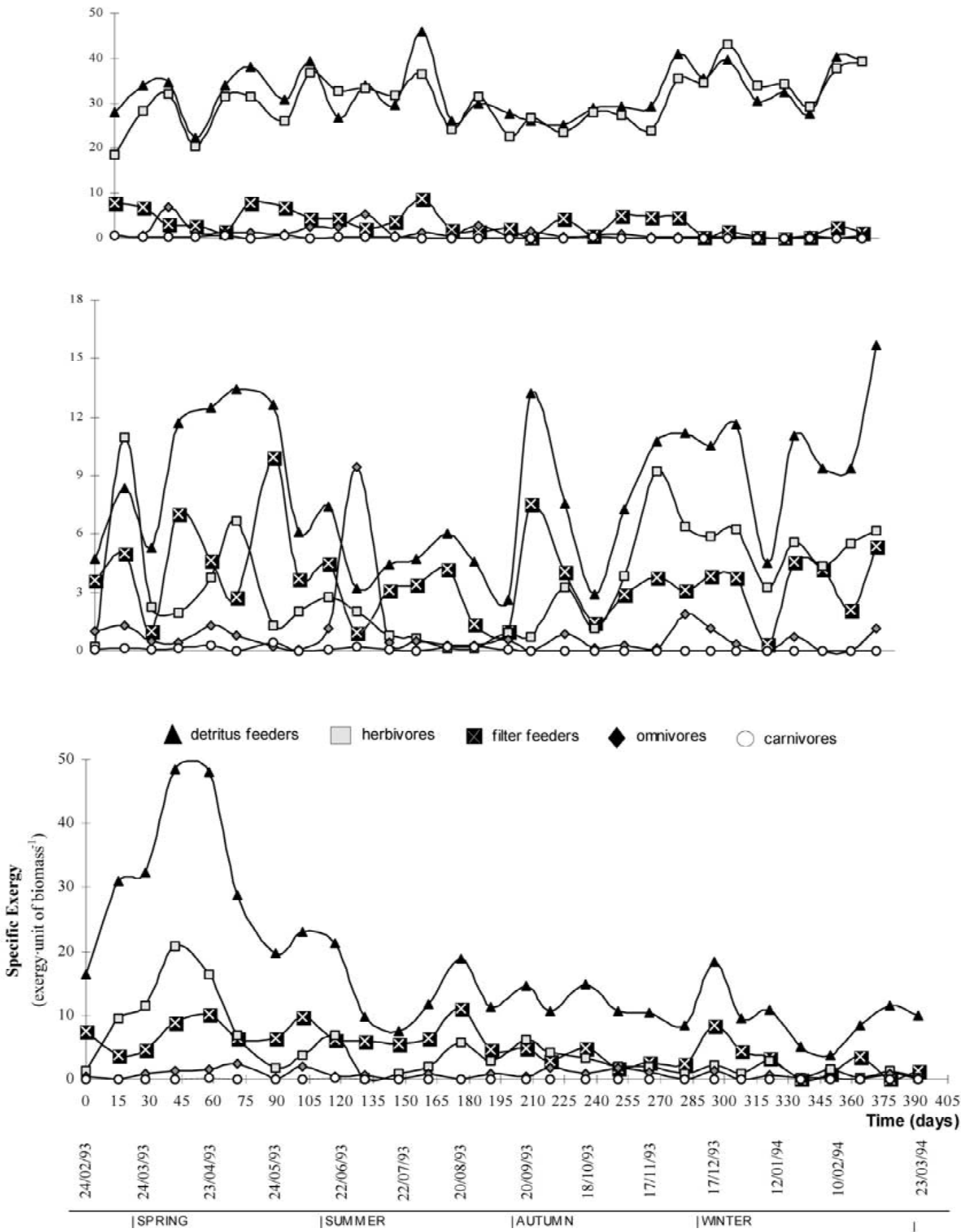

Figure 4. Variation of specific exergy in Zoostera meadows (4.1), intermediate eutrophied (4.2) and most eutrophied (4.3) areas in the Mondego estuary, considering contributions from organism biomass of each trophic guild. 

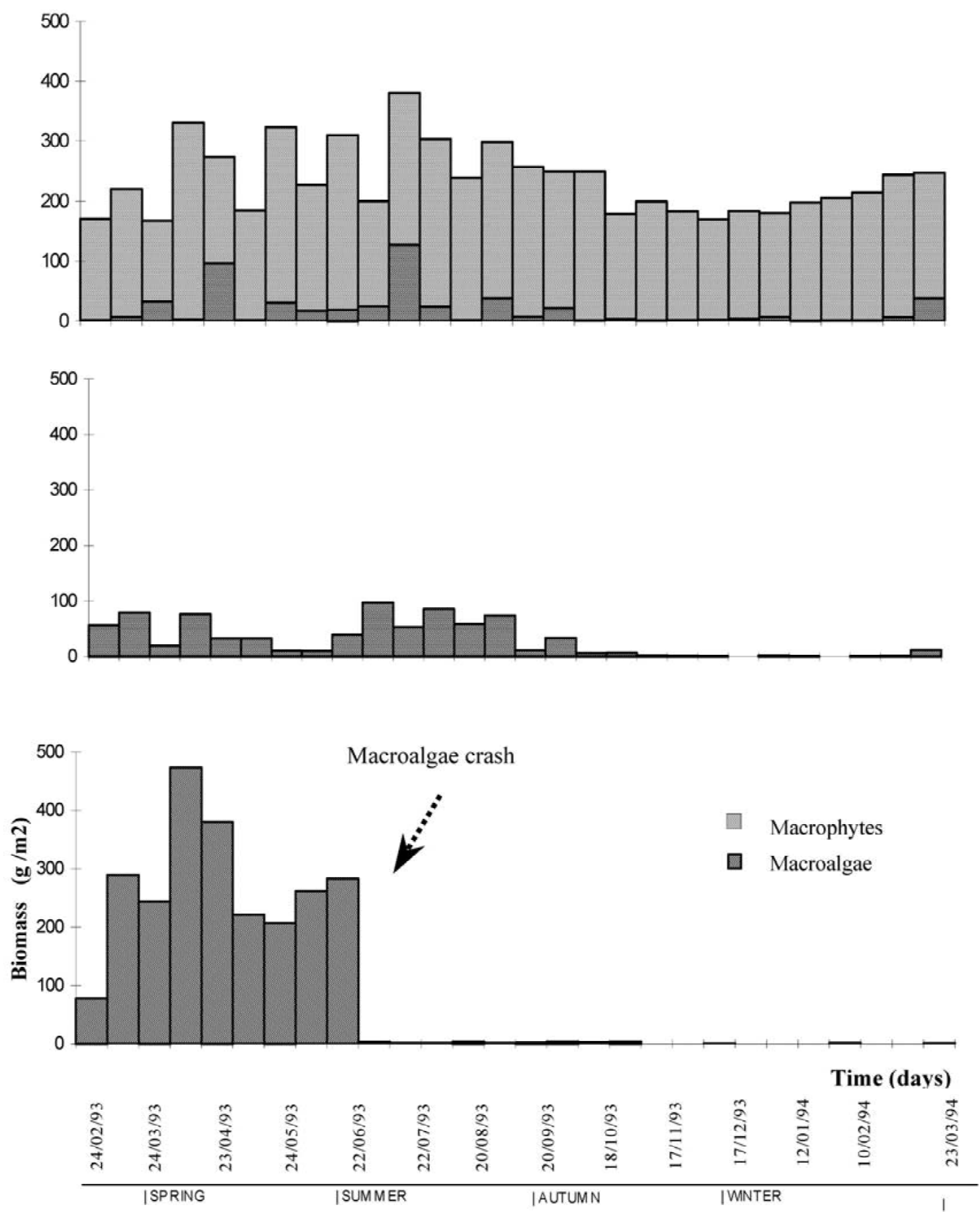

Figure 5. Variation of biomass density of primary producers found in Zoostera meadows (5.1), intermediate eutrophied (5.2) and most eutrophied (5.3) areas in the Mondego estuary. Macrophytes correspond to Zostera noltii biomass and Macroalgae to Ulva, Chaetomorpha, and Enteromorpha biomass. Data provided in Pardal (1998). 
work, which is dissipated as heat without a temperature gradient (Strapkraba et al., 1999; Jørgensen et al., 1999). In ecological terms, the concept of exergy is interpreted as a measure for the available energy invested by an ecosystem in maintaining and building its structure far from the thermodynamic equilibrium (Jørgensen, 1992b, c; Schneider \& Kay, 1994a, b, 1995; Jørgensen, 1997; Jørgensen et al., 1999). The use of this concept in ecological studies, although necessarily with great approximations, requires the estimation of the relative amount of exergy embedded in the biomass. Therefore, the weighing parameter $\beta$ is taken as a discriminator of the exergy (organizational) level of biomass in Equation (1). We have used values for the $\beta$ parameter described in Fonseca et al. (2000), which were determined from the nuclear DNA contents of organisms as more operational approach for the estimation of exergy from organism biomass in Fonseca et al. (2000).

Values of exergy and specific exergy were calculated from the biomass of the different organisms periodically sampled along an estuarine gradient of eutrophication in the Mondego estuary. During the first 4 months of the sampling period, the biomass of primary producers was followed by higher exergy estimates in the system, particularly in the most eutrophied area. Also, exergy estimates in the most eutrophied area were, on average, higher than in the intermediate eutrophied area. Therefore, it seems that higher exergy levels correspond to more stabilized levels at either end of the eutrophication gradient, as found in the communities around both the Zostera meadows (non-eutrophied area) and Enteromorpha (most eutrophied area) populations. On the other hand, on average, higher specific exergy estimates were associated with the populations in the intermediate eutrophied area, and in the most eutrophied area after the macroalgae crash. According to the results, the macroalgae crash may be interpreted as a disturbance bringing the most eutrophied area to the same state as the intermediate eutrophied area. Thus, higher exergy levels and lower exergy content per unit of biomass (specific exergy) seem to be associated with more stabilized populations or less perturbed areas. This way, these indices may provide different and complementary indications about the structure/functioning of the system. Additionally, from one viewpoint, the specific exergy contributions of the several trophic groups in the area B seem to oscillate between the levels found in the areas A and C. On the other hand, the exergy content per unit of biomass of detritus feeder and filter feeder organisms are higher in the eutrophied areas, particularly for the filter feeder organisms during late spring and early summer. This is a putative indication of the shift from a primary production based situation towards a detritus based food web (Marques et al., 1997). Therefore, the results correspond to field observations describing that in the intermediate eutrophied area the recruitment of new individuals (juveniles) may occur both from the macrophytes and the macroalgae communities, but the levels of disturbance do not stimulate the establishment of new organisms (Pardal, 1998).

Results obtained from the estimation of both exergy and specific exergy, for the considered estuarine system, were based on weighing factors $(\beta)$ determined by the application of organisms' nuclear DNA contents (Fonseca et al., 2000). Results provided good indications of the qualitative alterations occurring in the system and are useful in the evaluation of the environmental impact due to the eutrophication process.

From a more global point of view, what might be the contribution of this study for the general hypothesis on exergy optimisation? It appears more and more evident that a critical need in Ecology is to develop theoretical scaffolding capable of explaining results obtained up to now in terms of an accepted pattern. The aim should be to build in Ecology the equivalent of physical theory - 'equivalent' in the sense that the laws explaining observations derive from a very few fundamental laws (Jørgensen \& Marques, 2001). The efforts of many researchers over quite a few years will be necessary to develop such a theoretical network, and progress will be stepwise and, considering the difficulties, slow (Jørgensen \& Marques, 2001). Exergy optimisation in developing ecosystems represents a node in this theoretical network.

It is evidently critical to find ways to integrate large sets of observations and databases, and to interpret the scientific basis, results, and predictions clearly. In the present paper we intended to contribute to establish a bridge between empirical observations and theory. In fact, why should empirical researchers, environmental managers, and lay stakeholders care at all about theory? The only possible answer is, because a theoretical frame provides the context wherein researchers and others can interpret and integrate empirical results. Without integration and interpretation of raw observations within a consistent theoretical frame, only 
description is possible, not basic understanding that can be transmitted.

\section{Acknowledgements}

Authors are grateful to their colleagues at IMAR for their assistance during field and laboratory work. This work was supported by the Portuguese Science and Technology Foundation (Projects: PBICT/MAR/2253/95 and PRAXIS/P/MGS/ 11238/1998) and by the European Union (Project: FMRX-CT96-0051).

\section{References}

Azeiteiro, U. M. M., 1999. Ecologia Pelágica do Braço Sul do Estuário do Rio Mondego. Ph.D Thesis. Faculdade de Ciências e Tecnologia da Universidade de Coimbra, Coimbra: 213 pp.

Baird, D., 1998. Case Studies: Orientors and Ecosystems Properties in Coastal Zones. In Müller, M. \& M. Leupelt (eds), Eco Targets, Goal Functions, and Orientors. Springer-Verlag, Berlin: 232-242.

Bass, B., 1998. Applying Thermodynamic Orientors: Goal Functions in the Holling Figure-Eigth Model. In Müller, F. \& M. Leupelt (eds), Ecotargets, Goal Functions, and Orientors. Springer-Verlag, Berlin, Germany: 193-208.

Bossel, H., 1992. Real-structure process description as the basis of understanding ecosystems and their development. Ecol Model. 63: 261-276.

Bossel, H., 1998. Ecological Orientors: emergence of basic orientors in evolutionary self organization. In Müller, M. \& M. Leupelt (eds), Eco Targets, Goal Functions, and Orientors. Springer-Verlag, Berlin: 19-33.

Bröring, U. \& G. Wiegleb, 1998. Ecological Orientors: Pattern and Process of Sucession in Relation to Ecological Orientors. In Müller, M. \& M. Leupelt (eds), Eco Targets, Goal Functions, and Orientors. Springer-Verlag, Berlin: 34-62.

Costanza, R., B. G. Norton \& B. D. Haskel, 1992. Ecosystem Health - New Goals for Environmental Management. Island Press, Washington DC: 269 pp.

Duarte, D. R. \& R. P. Reis, 1993. Contribuição para a caracterização hidrodinâmica do estuário do Mondego. In Resumos da $3^{\mathrm{a}}$ Reunião do Quaternário Ibérico. Coimbra.

Flindt, M. R., L. Kamp-Nielsen, J. C. Marques, M. A. Pardal, M. Bocci, G. Bendoricchio, S. N. Nielsen \& S. E. Jørgensen, 1997. Description and comparison of three shallow estuaries: Mondego river (Portugal), Roskield Fjord (Denmark) and the lagoon of Venice (Italy). Ecol. Model. 102: 17-31.

Fuliu, Xu, 1997. Exergy and structural exergy as ecological indicators for the state of the Lake Chaolu ecosystem. Ecol. Model. 99: 41-49.

Jørgensen, S. E., 1992a. Integration of Ecosystem Theories: a Pattern. Kluwer Academic Publishers, Dordrecht: 380 pp.

Jørgensen, S. E., 1992b. Exergy and ecology. Ecol. Model. 63: 185214.

Jørgensen, S. E., 1992c. Development of models to account for changes in species composition. Ecol. Model. 62: 195-208.
Jørgensen, S. E. \& H. Mejer, 1977. Ecological Buffer capacity. Ecol. Model. 3: 39-61.

Jørgensen, S. E. \& H. Mejer, 1979. A holistic approach to ecological modeling. Ecol. Model. 7: 169-189.

Jørgensen, S. E. \& H. Mejer, 1981. Exergy as a key function in ecological models. In Mitsch, W. J., R. W. Bosserman \& J. M. Klopatek (eds), Energy and Ecological Modeling. Elsevier, Amsterdam: 587-590.

Jørgensen, S. E., B. C. Patten \& M. Straškraba, 1992. Ecosystems emerging: toward an ecology of complex systems in a complex future. Ecol Model. 62: 1-28.

Jørgensen, S. E., S. N. Nielsen \& H. Mejer, 1995. Emergy, environ exergy and ecological modeling. Ecol. Model. 77: 99-109.

Jørgensen, S. E. \& J. Padisak, 1996. Does the intermediate disturbance hypothesis comply with thermodynamics? Hydrobiologia 323: 9-21.

Jørgensen, S. E. \& R. Bernardi, 1997. The application of a model with dynamic structure to simulate the effect of mass fish mortality on zooplankton structure in Lago di Annone. Hydrobiologia 356: 87-96.

Jørgensen, S. E. \& S. N. Nielsen, 1998a. Thermodynamic Orientors: exergy as a Goal Function in Ecological Modeling an as an Ecological indicator for the Description of Ecosystem Development. In Müller, M. \& M. Leupelt (eds), Eco Targets, Goal Functions, and Orientors. Springer-Verlag, Berlin: 63-86.

Jørgensen, S. E. \& S. N. Nielsen, 1998b. Thermodynamic Orientors: a review of Goal Functions and Ecosystem Indicators. In Müller, M. \& M. Leupelt (eds), Eco Targets, Goal Functions, and Orientors. Springer-Verlag, Berlin: 123-136.

Jørgensen, S. E., B. C. Patten \& M. Straškraba, 1999. Ecosystems emerging: 3. Openness. Ecol. Model. 117: 41-64.

Jørgensen, S. E., B. C. Patten \& M. Straškraba, 2000. Ecosystems emerging: 4. growth. Ecol. Model. 126: 249-284.

Jørgensen, S. E. \& J. C. Marques, 2001. Thermodynamics and ecosystem theory, case studies from hydrobiology. Hydrobiologia 445: 1-10.

Kutsch, W., O. Dilly, W. Steinborn \& F. Müller, 1998. Quantifying Ecosystems Maturity - a Case Study. In Müller, M. \& M. Leupelt (eds), Eco Targets, Goal Functions, and Orientors. Springer-Verlag, Berlin: 209-231.

Lillebø, A. I., M. A. Pardal \& J. C. Marques, 1999. Population structure, dynamics and production of Hydrobia ulvae (Pennant) (Mollusca: Prosobranchia) along an eutrophication gradient in the Mondego estuary (Portugal). In Marques, Gamito \& Ré (eds), Processes and Flows in Marine Benthic Ecosystems. Acta Oecologica, 20 (4): 289-304.

Marques, J. C., 1989. Amphipoda (Crustácea) bentónicos da Costa Portuguesa: Estudo taxonómico, ecológico e biogeográfico. Ph.D Thesis. Universidade de Coimbra, Coimbra: 394 pp.

Marques, J. C., P. Maranhão \& M. A. Pardal, 1993. Human impact assessment on the subtidal macrobenthic community structure in the Mondego estuary (Western Portugal). Estuar. coast. shelf Sci. 37: 403-419.

Marques, J. C., M. A. Pardal, S. N. Nielsen \& S. E. Jørgensen, 1997. Analysis of the properties of exergy and biodiversity along an estuarine gradient of eutrophication. Ecol. Model. 102: 155-167.

Marques, J. C., M. Â. Pardal, S. N. Nielsen \& S. E. Jørgensen, 1998a. Thermodynamic Orientors: Exergy as a Holistic Ecosystem Indicator: A Case Study. In Müller, M. \& M. Leupelt (eds), Eco Targets, Goal Functions, and Orientors. Springer-Verlag, Berlin: 87-101.

Marques, J. C., S. N. Nielsen \& S. E. Jørgensen, 1998b. Applying Thermodynamic Orientors: The Use of Exergy as an Indicator in Environmental Manager. In Müller, M. \& M. Leupelt (eds), Eco 
Targets, Goal Functions, and Orientors. Springer-Verlag, Berlin: 481-491.

Martins, I., M. A. Pardal, A. I. Lillebø, M. R. Flindt \& J. C. Marques 2000. Hydrodynamics as a major factor controlling the occurrence of green macroalgae blooms in an eutrophic estuary: a case study. Estuar. coast. shelf Sci. (in press).

May, R. M., 1974. Biological populations with non-overlapping generations: stable points, stable cycles, and chaos. Science 186: 645-647.

Müller, F., 1997. State-of-the-art in ecosystem theory. Ecol. Model. 100: 135-161.

Müller, F. \& B. Fath, 1998. The Physical Basis of Ecological Goal Functions - Fundamentals, Problems and Questions. In Müller, M. \& M. Leupelt (eds), Eco Targets, Goal Functions, and Orientors. Springer-Verlag, Berlin: 269-285.

Müller, F., M. Leupelt, E. Reiche \& B. Breckling, 1998. Targets, Goal and Orientors. In Müller, M. \& M. Leupelt (eds), Eco Targets, Goal Functions, and Orientors. Springer-Verlag, Berlin: 3-11.

Nielsen, S. N., 1990. Application of exergy in structural-dynamic modelling. Verh. int. Ver. Limonol. 24: 641-645.

Nielsen, S. N., 1992. Strategies for structural-dynamical modelling. Ecol. Model. 63: 91-102.

Nielsen, S. N., 1994. Modelling structural dynamical changes in a Danish shallow lake. Ecol. Model. 73: 13-30.

Nielsen, S. N., 1995. Optimization of exergy in a structural dynamic model. Ecol Model. 77: 111-122.

Nielsen, S. N., S. E. Jørgensen \& J. C. Marques, 1998. Case Studies: Modeling Approaches for the Practical Application of Ecological Goal Functions. In Müller, M. \& M. Leupelt (eds), Eco Targets, Goal Functions, and Orientors. Springer-Verlag, Berlin: 243-254.

Odum, E. P., 1969. The strategy of ecosystem development. Science 164: 262-270.

Odum, H. T., 1983. Systems Ecology: an Introduction. Wiley, New York.

Okubo, A., 1986. Dynamical aspects of animal grouping: Swarms, schools, flocks, and herds. Adv. Biophys. 22: 1-94.

Pardal, M. A. C., 1995. Variação espacial e temporal das populações de poliquetas no estuário do Mondego. Dinâmica e produção de Amage adspersa (Grube, 1863). M.Sc Thesis. Faculdade de Ciências e tecnologia da Universidade de Coimbra, Coimbra: $121 \mathrm{pp}$.

Pardal, M. A. C., 1998. Impacto da eutrofização nas comunidades macrobentónicas do braço sul do estuário do Mondego (Portugal). Ph.D Thesis. Faculdade de Ciências e Tecnologia da Universidade de Coimbra, Coimbra: 315 pp.

Patten, B. C., 1998. Network Orientors: Steps Toward a Cosmography of Ecosystems: Orinetors for Directional Develop- ment, Self-Organization, and Autoevolution. In Müller, F. \& M. Leupelt (eds), Ecotargets, Goal Functions, and Orientors. Springer-Verlag, Berlin, Germany: 137-160.

Schneider, E. D. \& J. J. Kay, 1994a. Life as a Manifestation of the Second Law of Thermodynamics. Math. Comp. Model. 9 (6-8): 25-48.

Schneider, E. D. \& J. Kay, 1994b. Complexity and thermodynamicss: towards a new ecology. Futures 26: 626-647.

Schneider, E. D. \& J. J. Kay, 1995. Order from Disorder: the Thermodynamics of Complexity in Biology. In Murphy, M. P. \& L. A. J. O'Neill (eds), What is Life: The Next Fifty Years: Reflections on the Future of Biology. Cambridge Press, Cambridge: 161-172.

Schrödinger, E., 1944. What is Life? Cambridge University Press, Cambridge.

Søndergaard, M., E. Jeppsen, E. Mortensen, P. Dall, P. Kristensen \& O. Sortkjær, 1990. Phytoplankton biomass reduction after planktivorous fish reduction in a shallow, eutrophic lake: a combined effect of reduced internal P-loading and increased zooplankton grazing. Hydrobiologia 200/201: 229-240.

Straškraba, M., S. E. Jørgensen \& B. C. Patten, 1999. Ecosystems emerging: 2. Dissipation. Ecol. Model. 117: 3-39.

Svirezhev, Y., 1998. Thermodynamic Orientors: How to Use Thermodynamic Concepts in Ecology. In Müller, F. \& M. Leupelt (eds), Ecotargets, Goal Functions, and Orientors. SpringerVerlag, Berlim, Germany: 102-106.

Ulanowicz, R. E., 1998. Network Orientors: Theoretical and Philosophical Considerations why Ecosystems may Exhibit a Propensity to Increase in Ascendency. In Müller, F. \& M. Leupelt (eds), Ecotargets, Goal Functions, and Orientors. SpringerVerlag, Berlim, Germany: 176-192.

Wark, K., 1995. Advanced Thermodynamics for Engineers. McGraw-Hill, New York: 564 pp.

Weber, B. H., D. J. Depew, C. Dyke, S. N. Salthe, E. D. Schneider, R. E. Ulanowicz \& J. S. Wicken, 1989. Evolution in thermodynamic perspective: an ecological approach. Biol. Philo. 4: $373-405$.

Wilson, E. O., 1975. Sociobiology: The New Synthesis. Cambridge.

Woodley, S., J. Kay \& G. Francis, 1993. Ecological integrity and the management of ecosystems. Heritage Resources Centre, University of Waterloo and Canadian Park Service, Ottawa: 220 pp.

Zhou, J., S. Ma \& G. W. Hinman, 1996. Ecological exergy analysis: a new method for ecological energetics research. Ecol. Model. 84: 291-303.

Zölitz-Möller, R. \& S. Herrmann, 1998. Introduction: Orientors and Goal Functions for Environmental Planning - Questions and Outlines. In Müller, M. \& M. Leupelt (eds), Eco Targets, Goal Functions, and Orientors. Springer-Verlag, Berlin: 463-465. 